\title{
Influence of Meteorological Factors on Population Build-Up of Aphids and Natural Enemies on Summer Okra
}

\author{
Y.T. Jadhav ${ }^{*}$, B.V. Bhede ${ }^{2}$ and D.S. Shinde ${ }^{3}$ \\ ${ }^{1}$ Department of Agricultural Entomology, Ratnai Agriculture College, \\ Akluj -413101(M.S.), India \\ ${ }^{2}$ Department of Agricultural Entomology, Vasantrao Naik Marathwada Krishi Vidyapeeth, \\ Parbhani - 431402 (M.S.), India \\ ${ }^{3}$ Department of Agricultural Entomology, College of Agriculture, Paniv, India \\ *Corresponding author
}

The study on seasonal incidence of summer okra as influenced by weather parameters on aphid, lady bird beetle and syrphid fly showed its peak presence during $16^{\text {th }} \mathrm{MW}$ and

\section{Keywords}

Seasonal,

Correlation,

Regression,

Weather.

Article Info

Accepted:

20 February 2017

Available Online:

10 March 2017 maximum population of chyrsopa during $17^{\text {th }} \mathrm{MW}$, predatory spider during $20^{\text {th }} \mathrm{MW}$. The correlation studies indicated that aphid showed positively significant correlation with bright sunshine and negatively significant correlation with rainy days. While lady bird beetle, chrysopa and predatory spider showed positively significant correlation with maximum temperature, minimum temperature, evaporation and negatively significant correlation with morning RH and evening RH. Whereas syrphid fly revealed nonsignificant correlation. The equations of linear regression was set of aphid, lady bird beetle, chrysopa and predatory spider population by working out regression coefficient (b) and constant (a) but was not possible in syrphid fly population as the impact of all weather parameters were found non-significant. The multiple regression equation fitted were worked out and the coefficient of determination $\left(\mathrm{R}^{2}\right)$ mostly showed higher indication, hence the predictions and forewarning of the aphid and natural enemies population by using weather parameters were reliable.

\section{Introduction}

Okra in sanskrit is designated as 'Tindisha' and 'Gandhmula', originated from Africa and commonly known as "Lady's finger" or "Bhendi" which is a flowering plant under Malvaceae family producing high valued edible green pods showing good nutritional and multipurpose crop value. India ranks first in okra cultivation and production with an area of 532.64 thousand hectares and production of 6346.40 thousand tones along with productivity of $13.14 \mathrm{mt} / \mathrm{ha}$ (Anonymous,
2013). As high as 72 species of insects have been recorded on okra, hence known as the house of pests due to its two distinct i.e., vegetative and fruiting growing stages. Okra crop and its pest complex forms "okra ecosystem" which also includes natural enemies like predatory insects such as lady bird beetle and green lacewing feeding on aphid and soft bodied insects (Sekhon and Verma, 1983). 
Due to the above facts, the present investigation were undertaken with an objective to know seasonal incidence, correlation and regression among weather parameters against aphid and natural enemies population on summer okra.

\section{Materials and Methods}

A field study was conducted to know the summer season incidence, correlation and regression among weather parameters against okra aphid and natural enemies population at Department of Agricultural Entomology, Vasantrao Naik Marathwada Krishi Vidyapeeth, Parbhani during summer 2013 and 2014. Population count of aphid and natural enemies were taken from appearance of incidence upto the final harvest of crop on weekly basis without employing any plant protection measures on weekly basis by dividing experimental plot $(10 \mathrm{~m} \times 10 \mathrm{~m})$ into four equal quadra from which 5 plants from each were randomly selected of each plant top, middle and bottom leaves were considered. While in case of natural enemies whole plant was considered for recording their number. The different weather parameters recorded were collected from the meteorological unit and populations of Aphis gossypii and natural enemies were correlated with the meterological factors. The data obtained were averaged and subjected to simple correlation, linear and multiple regression analysis as per Panse and Sukhatme (1967).

\section{Results and Discussion}

The data regarding aphid and natural enemies infestation versus weather parameters during summer 2013 and 2014 (Pooled) study period were recorded with an objective to determine the trend in fluctuations of aphid and natural enemies population with respect to the weather conditions.

\section{Seasonal incidence of aphid (Aphis gossypii)}

The pooled incidence of aphids was observed throughout the crop season exhibiting a population range from 0.25 to 16.50 aphids $/ 3$ leaves (Table 1). The infestation observed was less during earlier stages of crop growth and went on increasing gradually achieving its highest peak of 16.15 aphids/3 leaves on $16^{\text {th }}$ standard week of April when the prevailing rainfall, maximum temperature, minimum temperature, morning relative humidity, evening relative humidity, evaporation, bright sunshine hours and wind velocity were $1.85 \mathrm{~mm}, 38.89^{\circ} \mathrm{C}, 22.04^{0} \mathrm{C}$, 58.79 per cent, 19.79 per cent, $10.10 \mathrm{hrs}, 9.87$ hrs, and $4.43 \mathrm{kmph}$, respectively. Later on the aphid population started declining reaching 1.83 aphids/3 leaves till $21^{\text {st }}$ standard week of May with an average mean incidence of 6.57 aphids/3 leaves. The present findings are in close aggreement with the results of Anitha and Nandihalli (2008) who studied the seasonal incidence of aphids and revealed that the activity of aphids was noticed throughout the cropping period during summer reached its peaks in the month of April. Shivanna et al. (2011) revealed that the population of aphid $45.07 \%$ per three leaves during May second forthnight and minimum temperature showed negative effect on aphid population.

\section{Overall seasonal incidence of natural enemies}

Pooled data regarding lady bird beetle population on summer okra crop reached its peak on $16^{\text {th }}$ standard week of April with 2.38 beetles per plant due to prevailing rainfall, maximum- minimum temperature, morningevening relative humidity, evaporation, bright sunshine hours and wind velocity of $1.85 \mathrm{~mm}$, $38.89^{0} \mathrm{C}, 22.04{ }^{0} \mathrm{C}, 58.79$ per cent, 19.79 per cent, $10.10 \mathrm{hrs}, 9.87 \mathrm{hrs}$, and $4.43 \mathrm{kmph}$, respectively. 
The chrysoperla incidence started more or less appearing from $12^{\text {th }}$ standard week of March, but was seen on regular basis from $14^{\text {th }}$ standard week of April with 0.25 grub/plant reaching highest population of 0.43 grubs/plant on $17^{\text {th }}$ standard week of April.

Syrphid fly population exhibited an high incidence of 4.0 syrphid fly/ plant during $16^{\text {th }}$ standard week of April when the corresponding rainfall, maximum- minimum temperature, morning-evening relative humidity, evaporation, bright sunshine hours and wind velocity were $1.85 \mathrm{~mm}, 38.89^{\circ} \mathrm{C}$, $22.04^{0} \mathrm{C}, 58.79$ per cent, 19.79 per cent, 10.10 hrs, $9.87 \mathrm{hrs}$, and $4.43 \mathrm{kmph}$.

The population of predatory spider was negligible and seen on regular basis from $16^{\text {th }}$ standard week of April (0.20 spider/ plant) which went on increasing and reached its peak incidence of 0.90 spider/ plant during $20^{\text {th }}$ standard week of May (Table 1).

The present results are in conformity with the findings of Hegde et al. (2004) who showed that natural enemies such as coccinellids, spiders and Chrysoperla carnea (Stephens) were found throughout the year. However, their population was very low. Anitha (2007) also noticed coccinellid population on summer crop during second week of April 2006 while chrysoperla population appeared during third week of April 06 and the peak incidence was noticed during fifth week of April 06 (0.56 grub/plant).

\section{Correlation and regression among weather parameters against aphid (Aphis gossypii)}

\section{Simple correlation studies}

The pooled data regarding correlation and regression coefficient between weather parameters and aphid population presented in Table 2 revealed that the non significant and negative correlation was observed between aphid population and rainfall, morning $\mathrm{RH}$, evening RH, wind velocity and evaporation. Positively non-significant correlation was observed between maximum temperature and minimum temperature and aphid population on okra. The data correlated between aphid population on okra and bright sunshine hour $\left(\mathrm{r}=0.538^{*}\right)$ was found positively significant, whereas with rainy days $\left(\mathrm{r}=-0.555^{*}\right)$ was negatively significant.

\section{Linear regression studies}

The pooled regression coefficient (b) and constant (a) were worked out to set regression equations (Table 2) revealed that correlation between aphid population and rainfall, minimum temperature, morning $\mathrm{RH}$, evening $\mathrm{RH}$ and bright sunshine on aphid on okra was not significant.

Only the rainy days and bright sunshine showed significant positive and negative impact. The regression equation worked out for rainy days (x) and aphid population (y) was $\mathrm{Y}=8.529-5.232 \mathrm{x}$ which indicated that the aphid population decreased by 0.555 for every unit increase in rainy days whereas the regression equation for bright sunshine was $\mathrm{Y}$ $=-33.32+4.345 \mathrm{x}$ which revealed that for every unit increase in bright sunshine the aphid population increased by 0.538 .

\section{Multiple correlation studies}

The pooled multiple regression coefficient for different weather parameters were worked and the multiple regression equation fitted with weather parameters in order to predict aphid population on okra was as,

$$
\begin{aligned}
& Y=-77.874+1.220 \mathrm{X}_{1}-18.878 \mathrm{X}_{2}+2.319 \\
& \mathrm{X}_{3}-0.142 \mathrm{X}_{4}-1.161 \mathrm{X}_{5}+1.483 \mathrm{X}_{6}- \\
& 3.248 \mathrm{X}_{7}+7.815 \mathrm{X}_{8}-0.347 \mathrm{X}_{9}
\end{aligned}
$$


The coefficient of determination $\left(\mathrm{R}^{2}\right)$ was 89 per cent (Table 3).

The correlation studies revealed that the present findings are in conformity with those of Sattar et al. (2009) studied on population dynamics of A.gossypii in relation with abiotic and biotic factors studied on okra, revealed that correlation of bright sunshine was significantly positive and partly agree with those of Singh et al. (2013) revealed that aphid population showed negative correlation with rainfall and maximum and minimum relative humidity.

\section{Correlation and regression among weather parameters against natural enemies}

\section{Lady bird beetle}

\section{Simple correlation studies}

The pooled data pertaining to simple correlation and regression coefficients between weather parameters and lady bird beetle population are presented in Table 2 which showed that the correlation between lady bird beetle population on okra and maximum temperature $\left(\mathrm{r}=0.568^{*}\right)$, minimum temperature $\left(\mathrm{r}=0.547^{*}\right)$ and bright sunshine $\left(\mathrm{r}=0.629^{*}\right)$ were found positively significant, whereas with morning relative humidity $(\mathrm{r}=$ $\left.0.617^{*}\right)$ and evening relative humidity ( $\mathrm{r}=$ $0.594 *)$ were negatively significant.

The non significant and negative correlation was observed between lady bird beetle population and rainfall and rainy days. The results brought out positive and non significant correlation between evaporation, wind velocity and lady bird beetle population on okra.

\section{Linear regression studies}

Linear regression was worked out between the weather parameters and incidence of lady bird beetle on okra. The pooled regression coefficient (b) and constant (a) were worked out and linear regression equations were set up. The impact of rainfall, rainy days, evaporation and wind velocity was non significant.

The correlation between maximum temperature, minimum temperature, bright sunshine and lady bird beetle population were positively significant. The regression equation worked out were $\mathrm{Y}=-3.875+0.125 \mathrm{x}, \mathrm{Y}=$ $4.779+0.114 \mathrm{x}$ and $\mathrm{Y}=-4.106+0.556 \mathrm{x}$ which indicated that for every unit increase in maximum temperature, the lady bird beetle population on okra increased by $0.568,0.547$ and 0.629 .

While the regression equation worked out were $\mathrm{Y}=4.170-0.053 \mathrm{x}$ and $\mathrm{Y}=2.438$ $0.067 \mathrm{x}$ which showed that for every unit increase in morning $\mathrm{RH}$ and evening $\mathrm{RH}$ the lady bird beetle population on okra decreased by 0.617 and 0.594 .

\section{Multiple regression studies}

The multiple regression equation fitted with weather parameters in order to predict lady bird beetle population on okra was as below.

$\mathrm{Y}=11.503+0.048 \mathrm{X}_{1}-0.719 \mathrm{X}_{2}-0.475 \mathrm{X}_{3}$ $+0.398 X_{4}-0.066 X_{5}-0.074 X_{6}$

$-0.335 \mathrm{X}_{7}+0.830 \mathrm{X}_{8}+0.188 \mathrm{X}_{9}$.

The coefficient of determination $\left(\mathrm{R}^{2}\right)$ represents the proportion of common variation in the two variables.

The present investigations revealed that the weather parameters contributed 93.3 per cent of total variation in the population of lady bird beetle (Table 3 ) on okra which was very high indicating that the predictions were reliable. 


\section{Chrysopa}

\section{Simple correlation studies}

The data indicated that the correlation between maximum temperature $\left(r=0.674^{* *}\right)$, minimum temperature $\left(\mathrm{r}=0.666^{* *}\right)$, evaporation $\left(\mathrm{r}=0.621^{*}\right)$, bright sunshine $(\mathrm{r}=$ $\left.0.611^{*}\right)$ and chrysopa population was positive and significant whereas, negatively significant correlation was observed between chrysopa population on okra and morning $\mathrm{RH}(\mathrm{r}=-$ $\left.0.649^{*}\right)$, evening relative humidity $(\mathrm{r}=$ $0.570^{*}$ ). The correlations of rainfall and rainy days with chrysopa population were found negatively non- significant while wind velocity was positive and non-significant.

\section{Linear regression studies}

The pooled regression equations were set by working out regression coefficient (b) and constant (a) (Table 2) showing that the impact of rainfall, rainy days and wind velocity was non-significant.

The chrysopa population on okra were positive and significantly correlated with maximum temperature, minimum temperature, evaporation and bright sunshine. The regression equations worked out were $\mathrm{Y}$ $=-1.230+0.036 \mathrm{x}, \mathrm{Y}=-0.560+0.034 \mathrm{x}, \mathrm{Y}=$ $-0.276+0.044 \mathrm{x}$ and $\mathrm{Y}=-1.030+0.132 \mathrm{x}$ which indicated that for every unit increase in maximum temperature, minimum temperature, evaporation and bright sunshine the chrysopa population on okra increased by $0.674,0.666,0.621$ and 0.611 .

The regression equations worked out were $\mathrm{Y}$ $=1.003-0.014 \mathrm{x}$ and $\mathrm{Y}=0.525-0.016 \mathrm{x}$ showed that for every unit increase in morning $\mathrm{RH}$ and evening $\mathrm{RH}$ the chrysopa population on okra decreased by 0.649 and 0.570 .

\section{Multiple regression studies}

Multiple regression coefficients for different weather parameters were worked out (Table $3)$. The pooled multiple regression equation with weather parameters in order to predict chrysopa population was as below,

$$
\begin{aligned}
& Y=1.487+0.029 X_{1}-0.137 X_{2}-0.270 X_{3}+ \\
& 0.225 X_{4}+0.001 X_{5}-0.017 X_{6} \\
& +0.198 X_{7}+0.348 X_{8}-0.184 X_{9} .
\end{aligned}
$$

The coefficient of determination $\left(\mathrm{R}^{2}\right)$ was 82.4 per cent. This indicated that the total variation in the population of chrysopa on okra was 82.4 per cent due to different weather parameters.

\section{Syrphid fly}

\section{Simple correlation studies}

The pooled data on simple correlation and regression coefficients between syrphid fly population and weather parameters are presented in Table 2 which showed no positive and negative significant correlation between syrphid fly population on okra and different weather parameters.

The correlation of rainfall, rainy days, morning RH and evening relative humidity with syrphid fly population were negatively non- significant. The syrphid fly population correlated positively non- significant relationship with maximum temperature, minimum temperature, evaporation, bright sunshine and wind velocity.

\section{Linear regression studies}

The regression equations could not be set by working out regression coefficient (b) and constant (a) (Table 21) as the impact of rainfall, rainy days, maximum temperature, minimum temperature, morning $\mathrm{RH}$, evening 
RH, evaporation, bright sunshine and wind velocity were non-significant.

\section{Multiple regression studies}

Multiple regression coefficients for different weather parameters were worked out (Table 4 ). The pooled multiple regression equation with weather parameters in order to predict syrphid fly population was worked out as below.
$\mathrm{Y}=22.714+0.035 \mathrm{X}_{1}-1.266 \mathrm{X}_{2}-0.733 \mathrm{X}_{3}$

$+0.419 \mathrm{X}_{4}-0.170 \mathrm{X}_{5}-0.040 \mathrm{X}_{6}$

$-0.953 X_{7}+1.767 X_{8}+0.669 X_{9}$.

The coefficient of determination $\left(\mathrm{R}^{2}\right)$ between weather parameters and syrphid fly population on okra was significant with 90.9 per cent showing the importance of these parameters influencing the abundance of syrphid fly on okra.

Table.1 Seasonal incidence of aphid and their natural enemies on okra (pooled of summer 2013 and 2014)

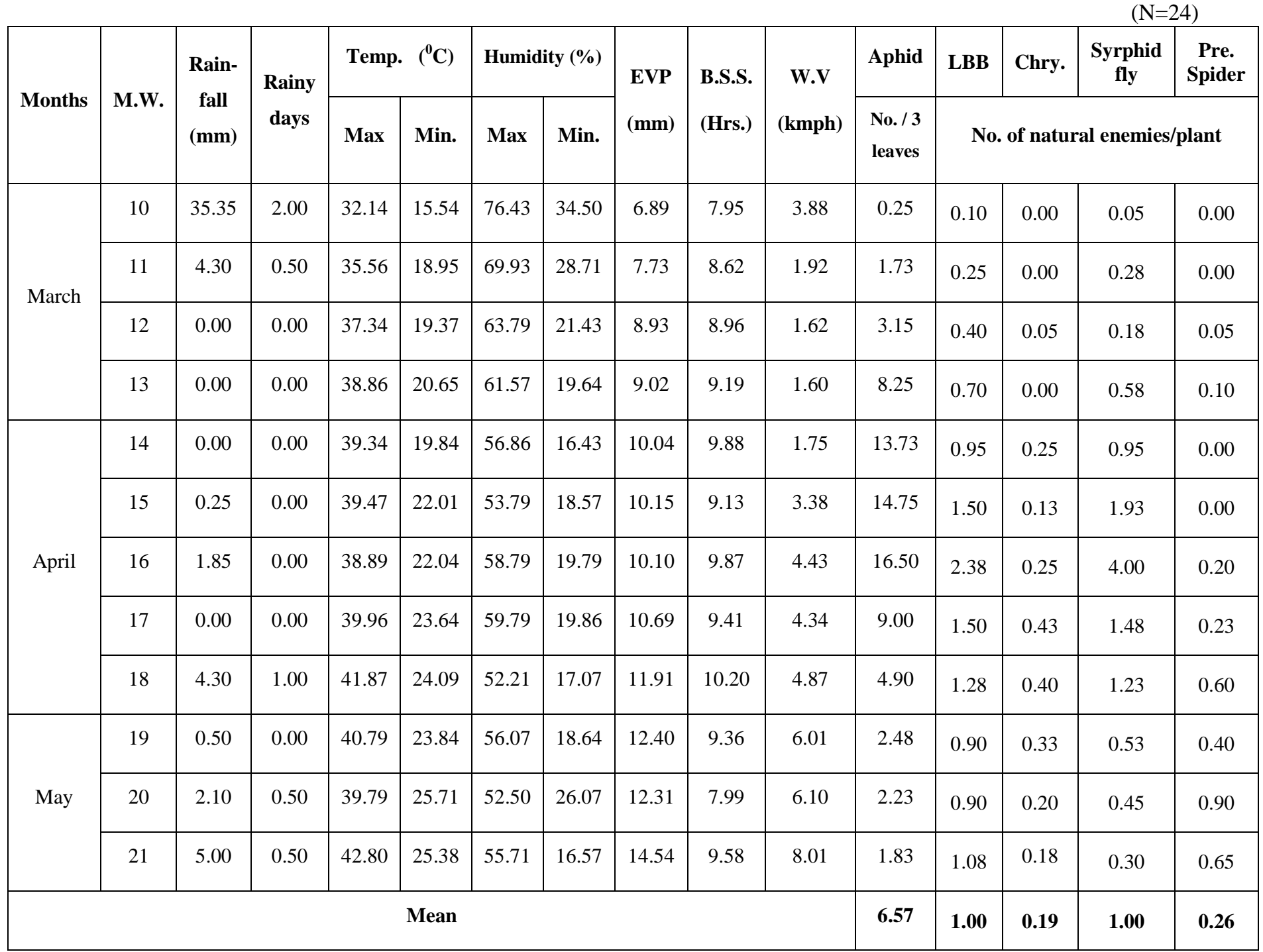


Table. 2 Correlation and linear regression coefficients between aphid and their natural enemies on okra (pooled of summer 2013 and 2014)

\begin{tabular}{|c|c|c|c|c|c|c|c|c|c|c|c|c|c|c|c|}
\hline \multirow{2}{*}{$\begin{array}{c}\text { Weather } \\
\text { Parameters }\end{array}$} & \multicolumn{3}{|c|}{ Aphid Population } & \multicolumn{3}{|c|}{ LBB Population } & \multicolumn{3}{|c|}{ Chrysopa Population } & \multicolumn{3}{|c|}{ Syrphid fly Population } & \multicolumn{3}{|c|}{$\begin{array}{c}\text { Predatory Spider } \\
\text { Population }\end{array}$} \\
\hline & $\mathbf{r}$ & $\mathbf{b}$ & $\mathbf{a}$ & $\mathbf{r}$ & $\mathbf{r}$ & $\mathbf{r}$ & $\mathbf{r}$ & $\mathbf{b}$ & $\mathbf{a}$ & $\mathbf{r}$ & $\mathbf{b}$ & $\mathbf{a}$ & $\mathbf{r}$ & $\mathbf{b}$ & $\mathbf{a}$ \\
\hline Rainfall (mm) & -0.425 & -0.246 & 7.667 & -0.449 & -0.028 & 1.122 & -0.372 & -0.006 & 0.211 & -0.287 & -0.032 & 1.140 & -0.170 & -0.005 & 0.284 \\
\hline Rainy days & $-0.555^{*}$ & -5.232 & 8.529 & -0.449 & -0.463 & 1.169 & -0.236 & -0.060 & 0.207 & -0.357 & -0.650 & 1.240 & 0.098 & 0.050 & 0.242 \\
\hline Temp. ${ }^{0} \mathrm{C}$ Max. & 0.219 & 0.441 & -10.60 & $0.568^{*}$ & 0.125 & -3.875 & $0.674 * *$ & 0.036 & -1.230 & 0.222 & 0.086 & -2.350 & $0.625^{*}$ & 0.067 & -2.366 \\
\hline Temp. ${ }^{{ }^{C C}}$ Min. & 0.043 & 0.082 & 4.779 & $0.547 *$ & 0.114 & 4.779 & $0.666 * *$ & 0.034 & -0.560 & 0.199 & 0.073 & -0.598 & $0.827 * *$ & 0.085 & -1.581 \\
\hline R.H (\%) AM & -0.361 & -0.284 & 23.52 & $-0.617 *$ & -0.053 & 4.170 & $-0.649 *$ & -0.014 & 1.003 & -0.324 & -0.049 & 3.927 & $-0.610^{*}$ & -0.026 & 1.799 \\
\hline R.H (\%) PM & -0.511 & -0.529 & 17.92 & $-0.594 *$ & -0.067 & 2.438 & $-0.570 *$ & -0.016 & 0.525 & -0.354 & -0.071 & 2.511 & -0.193 & -0.011 & 0.491 \\
\hline EVP & -0.057 & -0.151 & 8.137 & 0.434 & 0.127 & -0.320 & $0.621 *$ & 0.044 & -0.276 & 0.058 & 0.030 & 0.686 & $0.815 * *$ & 0.117 & -0.950 \\
\hline BSS (hr./day) & $0.538^{*}$ & 4.345 & -33.32 & $0.629^{*}$ & 0.556 & -4.106 & $0.611 *$ & 0.132 & -1.030 & 0.506 & 0.788 & -6.238 & 0.025 & 0.011 & 0.163 \\
\hline W.V (kmph) & -0.299 & 0.302 & 9.889 & 0.318 & 0.097 & 0.608 & 0.476 & 0.036 & 0.043 & 0.034 & 0.018 & 0.924 & $0.809 * *$ & 0.121 & -0.221 \\
\hline $\begin{array}{l}\text { Number of } \\
\text { observations }\end{array}$ & 24 & 24 & 24 & 24 & 24 & 24 & 24 & 24 & 24 & 24 & 24 & 24 & 24 & 24 & 24 \\
\hline
\end{tabular}


Table.3 Multiple regression coefficients between weather parameters and aphid, lady bird beetle, chrysopa population on okra (pooled of summer 2013 and 2014)

\begin{tabular}{|c|c|c|c|c|c|c|c|c|c|}
\hline \multirow{3}{*}{$\begin{array}{c}\text { Sucking } \\
\text { pests }\end{array}$} & \multicolumn{9}{|c|}{ Pooled correlation coefficient values $(r)$} \\
\hline & \multirow{2}{*}{$\begin{array}{c}\text { Rainfall } \\
(\mathbf{m m}) \\
\left(\mathbf{X}_{1}\right)\end{array}$} & \multirow{2}{*}{$\begin{array}{c}\text { Rainy } \\
\text { days } \\
\left(\mathbf{X}_{2}\right)\end{array}$} & \multicolumn{2}{|c|}{$\begin{array}{c}\text { Temperature } \\
\qquad\left(C^{0}\right)\end{array}$} & \multicolumn{2}{|c|}{$\begin{array}{c}\text { Relative humidity } \\
(\%)\end{array}$} & \multirow{2}{*}{$\begin{array}{c}\text { Evapor } \\
\text {-ation } \\
\left(\mathbf{X}_{7}\right)\end{array}$} & \multirow{2}{*}{$\begin{array}{c}\text { BSS } \\
\text { (Hrs.) } \\
\left(\mathbf{X}_{8}\right)\end{array}$} & \multirow{2}{*}{$\begin{array}{c}\text { Wind } \\
\text { velocity } \\
\left(\mathrm{X}_{9}\right)\end{array}$} \\
\hline & & & $\begin{array}{l}\text { Max. } \\
\left(\mathbf{X}_{3}\right)\end{array}$ & $\begin{array}{l}\text { Min. } \\
\left(\mathbf{X}_{4}\right)\end{array}$ & $\begin{array}{c}\text { Morning } \\
\left(\mathbf{X}_{5}\right)\end{array}$ & $\begin{array}{c}\text { Evening } \\
\left(\mathrm{X}_{6}\right)\end{array}$ & & & \\
\hline \multicolumn{10}{|l|}{ Aphid } \\
\hline $\mathrm{Bi}$ & 1.220 & -18.878 & 2.319 & -0.142 & -1.161 & 1.483 & -3.248 & 7.815 & -0.347 \\
\hline S.E. & 1.255 & 16.900 & 11.043 & 5.9657 & 0.738 & 3.743 & 6.676 & 7.936 & 5.714 \\
\hline ' $t$ ' values & 0.972 & -1.117 & 0.210 & -0.024 & 1.574 & 0.396 & -0.487 & 0.985 & -0.061 \\
\hline \multirow{2}{*}{$\begin{array}{l}\text { Path } \\
\text { coefficient }\end{array}$} & 2.109 & -2.002 & 1.153 & -0.075 & -1.478 & 1.433 & -1.220 & 0.968 & -0.125 \\
\hline & \multicolumn{2}{|c|}{$\mathbf{B}_{\mathbf{0}}=-77.874$} & \multicolumn{2}{|c|}{ F-val $=1.827$} & \multicolumn{3}{|c|}{$\mathbf{R}^{2}=0.890$} & \multicolumn{2}{|c|}{$\mathbf{S E Y}=4.427$} \\
\hline $\begin{array}{l}\text { LBB } \\
\mathrm{Bi}\end{array}$ & 0.048 & -0.719 & -0.475 & 0.398 & -0.066 & -0.074 & -0.335 & 0.830 & 0.188 \\
\hline S.E. & 0.108 & 1.451 & 0.948 & 0.512 & 0.063 & 0.321 & 0.573 & 0.682 & 0.491 \\
\hline 't' values & 0.449 & -0.496 & -0.501 & 0.778 & -1.034 & -0.231 & -0.585 & 1.217 & 0.383 \\
\hline \multirow{2}{*}{$\begin{array}{l}\text { Path } \\
\text { coefficient }\end{array}$} & 0.764 & -0.696 & -2.157 & 1.906 & -0.761 & -0.655 & -1.150 & 0.938 & 0.618 \\
\hline & \multicolumn{2}{|c|}{$\mathbf{B}_{\mathbf{0}}=11.503$} & \multicolumn{2}{|c|}{ F-val $=3.110$} & \multicolumn{3}{|c|}{$\mathbf{R}^{2}=0.933$} & \multicolumn{2}{|c|}{ SEY $=0.380$} \\
\hline $\begin{array}{l}\text { Chrysopa } \\
\mathrm{Bi}\end{array}$ & 0.029 & -0.137 & -0.270 & 0.225 & 0.001 & -0.017 & 0.198 & 0.348 & -0.184 \\
\hline S.E. & 0.043 & 0.578 & 0.377 & 0.204 & 0.025 & 0.128 & 0.228 & 0.271 & 0.195 \\
\hline ' $t$ ' values & 0.682 & -0.237 & -0.715 & 1.103 & 0.052 & -0.135 & 0.870 & 1.284 & -0.942 \\
\hline \multirow{2}{*}{$\begin{array}{l}\text { Path } \\
\text { coefficient }\end{array}$} & 1.887 & -0.540 & -5.005 & 4.393 & 0.062 & -0.621 & 2.779 & 1.609 & -2.470 \\
\hline & \multicolumn{2}{|c|}{$\mathbf{B}_{\mathbf{o}}=1.487$} & \multicolumn{2}{|c|}{$\mathbf{F}$-val $=1.039$} & \multicolumn{3}{|c|}{$\mathbf{R}^{2}=0.824$} & \multicolumn{2}{|c|}{$\mathbf{S E Y}=0.151$} \\
\hline
\end{tabular}


Table.4 Multiple regression coefficients between weather parameters and syrphid fly, predatory spider population on okra (pooled of summer 2013 and 2014)

\begin{tabular}{|c|c|c|c|c|c|c|c|c|c|}
\hline \multirow{3}{*}{$\begin{array}{l}\text { Sucking } \\
\text { pests }\end{array}$} & \multicolumn{9}{|c|}{ Pooled correlation coefficient values $(\mathbf{r})$} \\
\hline & \multirow{2}{*}{$\begin{array}{c}\text { Rainfall } \\
(\mathbf{m m}) \\
\left(\mathbf{X}_{1}\right)\end{array}$} & \multirow{2}{*}{$\begin{array}{c}\text { Rainy } \\
\text { days } \\
\left(\mathrm{X}_{2}\right)\end{array}$} & \multicolumn{2}{|c|}{$\begin{array}{c}\text { Temperature } \\
\qquad\left(C^{0}\right)\end{array}$} & \multicolumn{2}{|c|}{$\begin{array}{c}\text { Relative humidity } \\
(\%)\end{array}$} & \multirow{2}{*}{$\begin{array}{c}\text { Evapor } \\
\text {-ation } \\
\left(\mathrm{X}_{7}\right)\end{array}$} & \multirow{2}{*}{$\begin{array}{c}\text { BSS } \\
\text { (Hrs.) } \\
\left(\mathbf{X}_{8}\right)\end{array}$} & \multirow{2}{*}{$\begin{array}{c}\text { Wind } \\
\text { velocity } \\
\left(X_{9}\right)\end{array}$} \\
\hline & & & $\begin{array}{l}\text { Max. } \\
\left(\mathbf{X}_{3}\right)\end{array}$ & $\begin{array}{l}\text { Min. } \\
\left(\mathbf{X}_{4}\right)\end{array}$ & $\begin{array}{c}\text { Morning } \\
\left(\mathrm{X}_{5}\right)\end{array}$ & $\begin{array}{c}\text { Evening } \\
\left(\mathrm{X}_{6}\right)\end{array}$ & & & \\
\hline $\begin{array}{l}\text { Syrphid fly } \\
\mathrm{Bi}\end{array}$ & 0.035 & -1.266 & -0.733 & 0.419 & -0.170 & -0.040 & -0.953 & 1.767 & 0.669 \\
\hline S.E. & 0.222 & 2.984 & 1.950 & 1.052 & 0.130 & 0.661 & 1.17 & 1.401 & 1.009 \\
\hline ' $t$ ' values & 0.158 & -0.424 & -0.376 & 0.399 & -1.302 & -0.060 & -0.809 & 1.261 & 0.664 \\
\hline \multirow[b]{2}{*}{$\begin{array}{l}\text { Path } \\
\text { coefficient }\end{array}$} & 0.313 & -0.696 & -1.890 & 1.141 & -1.120 & -0.199 & -1.8546 & 1.135 & 1.250 \\
\hline & \multicolumn{2}{|c|}{$\mathbf{B}_{\mathbf{0}}=22.714$} & \multicolumn{2}{|c|}{ F-val $=2.221$} & \multicolumn{3}{|c|}{$\mathbf{R}^{2}=0.909$} & \multicolumn{2}{|c|}{ SEY $=0.782$} \\
\hline $\begin{array}{l}\text { Pre. Spider } \\
\mathrm{Bi}\end{array}$ & 0.010 & 0.156 & -0.157 & 0.171 & 0.002 & 0.021 & 0.279 & 0.132 & -0.182 \\
\hline S.E. & 0.042 & 0.571 & 0.373 & 0.201 & 0.025 & 0.126 & 0.226 & 0.268 & 0.193 \\
\hline ' $t$ ' values & 0.227 & 0.274 & -0.422 & 0.849 & 0.080 & 0.165 & 1.239 & 0.492 & -0.943 \\
\hline \multirow{2}{*}{$\begin{array}{l}\text { Path } \\
\text { coefficient }\end{array}$} & 0.310 & 0.309 & -1.457 & 1.669 & 0.048 & 0.375 & 1.954 & 0.305 & -1.220 \\
\hline & \multicolumn{2}{|c|}{$\mathbf{B}_{\mathbf{0}}=-1.394$} & \multicolumn{2}{|c|}{ F-val $=4.949$} & \multicolumn{3}{|c|}{$\mathbf{R}^{2}=0.957$} & \multicolumn{2}{|c|}{$\mathbf{S E Y}=0.150$} \\
\hline
\end{tabular}

\section{Predatory spider}

\section{Simple correlation studies}

The pooled data presented in Table 2 indicated that the correlation between maximum temperature $\left(\mathrm{r}=0.625^{*}\right)$, minimum temperature $\left(\mathrm{r}=0.827^{* *}\right)$, evaporation $(\mathrm{r}=$ $\left.0.815^{* *}\right)$, wind velocity $\left(\mathrm{r}=0.809^{* *}\right)$ and predatory spider population were positive and significant. Whereas negatively significant correlation was observed between predatory spider population on okra and morning $\mathrm{RH}(\mathrm{r}$ $=-0.610 *)$. The correlations of rainfall and evening RH with predatory spider population were found negatively non- significant while rainy days, bright sunshine was positive and non-significant.

\section{Linear regression studies}

The pooled regression equations were set by working out regression coefficient (b) and constant (a) showing that the impact of rainfall, rainy days, evening $\mathrm{RH}$ and wind velocity was found non-significant.

The predatory spider population on okra were positive and significantly correlated with maximum temperature, minimum temperature, evaporation and wind velocity. The regression equation worked out were $\mathrm{Y}=$ $-2.366+0.067 \mathrm{x}, \mathrm{Y}=-1.581+0.085 \mathrm{x}, \mathrm{Y}=-$ $0.950+0.117 \mathrm{x}$ and $\mathrm{Y}=-0.221+0.121 \mathrm{x}$ which indicated that for every unit increase in maximum temperature, minimum 
temperature, evaporation and wind velocity the predatory spider population on okra increased by $0.625,0.827,0.815$ and 0.809 .

While the regression equation worked out was $\mathrm{Y}=1.799-0.026 \mathrm{x}$ which showed that for every unit increase in morning $\mathrm{RH}$ the predatory spider population on okra decreased by 0.610 .

\section{Multiple regression studies}

Multiple regression coefficients for different weather parameters were worked out (Table 4). The pooled multiple regression equation with weather parameters in order to predict predatory spider population was as below,

$\mathrm{Y}=-1.394+0.010 \mathrm{X}_{1}+0.156 \mathrm{X}_{2}-0.157 \mathrm{X}_{3}+$ $0.171 \mathrm{X}_{4}+0.002 \mathrm{X}_{5}+0.021$ $\mathrm{X}_{6}+0.279 \mathrm{X}_{7}+0.132 \mathrm{X}_{8}-0.182 \mathrm{X}_{9}$.

The coefficient of determination $\left(\mathrm{R}^{2}\right)$ revealed that the weather parameters contributed about 95.7 per cent of total variation in the population of predatory spider on okra which was very high indicating that the predictions made were reliable.

The present findings are in agreement with those of Rao et al. (1989) who showed that both pest (B.tabaci) and natural enemy populations were decreased by rainfall and significant correlation of temperature with the population of predators. Purohit et al. (2006) showed that coccienllid population with abiotic factors such as rainfall, rainy days, evaporation and wind velocity had a nonsignificant correlation while Chrysoperla population had a significant negative correlation with morning and afternoon relative humidity. Anitha (2007) in her correlation studies revealed that parameters such as total rainfall had non significant relationship with coccinellid population. Correlation studies between various weather parameters and Chrysoperla population showed a significant negative correlation with morning and afternoon relative humidity.

\section{References}

Anitha, K. R. 2007. Seasonal Incidence and Management of Sucking Pests of Okra. M.Sc.(Agri) Thesis, University of Agricultural Sciences, Dharwad.

Anitha, K. R. and Nandihalli, B. S. 2008.Seasonal Incidence of Sucking Pests in Okra Ecosystem. Karnataka J. Agric. Sci., 21(1): 137-138.

Anonymous, 2013. Indian Horticultural Database 2013-14. National Horticultural Board, Ministry of Agriculture, Government of India.

Hegde, M., Srinivasa, M., Biradar, D. P., Udikeri, S. S. and Khadi, B. M. 2004. Seasonal Incidence of Key Insect Pests and Their Natural Enemies on Cotton at Siruguppa. Int. Symp. Start for Sust. Cotton prod. - A Global vision, 23-25, Karnataka, India, pp. 114-115.

Panse, V.G. and Sukhatme, P.V. 1967. Statistical Methods for Agricultural Workers, ICAR, New Delhi.

Purohit, D., Ameta, O. P. and Sarangdevot, S. S. 2006. Seasonal Incidence of Major Insect Pests of Cotton and Their Natural Enemies. Pestology, 30 (12): 24-29.

Rao, N.V., Reddy, A.S. and Rao, K.T. 1989. Natural Enemies of Cotton Whitefly, Bemisia tabaci Gennadius in Relation to Host Population and Weather Factors. J. Biol. Control, 3(1): 10-12.

Sattar Shah, M.A., Singh T.K. and Chhetry G.K.N. 2009. Population Dynamics of Aphid Infesting Okra at Manipur.Indian J. Entomol.,71(3): 206-208.

Sekhon, B.S. and Verma, G.C. 1983. Parasitoids of Pectinophora 
gossypiella and Earias spps. in Punjab. Entomophaga, 28(1): 45-53.

Shivanna, B.K., Naik, G., Basavaraja, M.K., Nagaraja, R., Kallevwara Swamy, C.M. and Karegowda C. 2011. Impact of Biotic Factors on Population Dynamics of Sucking Pests in Transgenic Cotton Ecosystem.
L.I.S.N., 1: 72-74.

Singh,Y.,Jha, A.,Verma S.,Mishra,V. K. and Singh,S. S. 2013.Population Dynamics of Sucking Insect Pests and its Natural Enemies on Okra Agro-Ecosystem in Chitrakoot Region.African J. Agril. Res., 8(28): 3814-3819.

\section{How to cite this article:}

Jadhav, Y.T., B.V. Bhede and Shinde, D.S. 2017. Influence of Meteorological Factors on Population Build-Up of Aphids and Natural Enemies on Summer Okra. Int.J.Curr.Microbiol.App.Sci. 6(3): 2527-2537. doi: https://doi.org/10.20546/ijcmas.2017.603.286 